\title{
Internet Governance : Some Thoughts after the two WSIS
}

\author{
Yves Poullet \\ University of Namur and of Liege (Belgium) \\ Director of Research Centre for Computer and Law \\ yves.poullet@fundp.ac.be
}

\begin{abstract}
The challenges faced by the globalisation of our Information Society are numerous and crucial for the future of our democracies. The two WSIS have tried to answer these challenges by proclaiming new rights and overall a new way for governing the Internet. This paper focuses on two major debates: the first one circumvents the right to "Universal Access" viewed as the right for everyone to become a "netizen". This includes participation in the Information Society, which incorporates not only the right to be connected to the infrastructure, not only the right to gain access to the informational richness available on the Net but also the possibility for everybody to take part in the large discussion forum that is the Internet. The discussion about Internet Governance was the major topic at the Tunis Agenda. The WSIS definitively advocated a transparent, multistakeholder and co-regulatory approach. What does this mean? What role might ICANN fulfil - do we need to reform that organisation? Among the stakeholders, particularly the international organisations, who are the real winners and who is losing? Might the EU approach to co-regulation be taken as a model for Internet governance? All these questions are raised, even if they are not solved, in our comments.
\end{abstract}

Keywords: WSIS, Internet Governance, Universal service, Co-regulation, ICANN.

1 The World Summit on the Information Society (WSIS) was held in two phases. The first phase took place in Geneva hosted by the Government of Switzerland from 10 to 12 December 2003, and the second phase took place in Tunis hosted by the Government of Tunisia, from 16 to 18 November 2005. As regards the preparatory documents and the outcomes of these two Summits, see: http://www.itu.int/wsis. One pinpoints the major documents issued by the two summits: Geneva Declaration of Principles, Geneva Plan of Action, Tunis Commitment, Tunis Agenda for the Information Society 
1. Jacques, you are interdisciplinary by conviction but also by the choice of your friends. With Stefano Rodota, I am your lawyer friend and very glad to be here among your other friends: computer scientists, economists, sociologists and philosophers. It is our pleasure, duty but overall our honour to express our deep acknowledgment and indebtedness vis-à-vis certain colleagues for both their scientific input and their human support. So before I start, I take this opportunity to thank you Jacques for all that you have brought to me. Thanks, Jacques, for your kindness and friendly support in certain important moments of my life.

As regards your presence in my private life, I will give no details. Stefano, you and $I$ assign great value to privacy in not commenting thereon but overall you know in your heart what I mean. As regards my professional life, I would like just to mention one of the most important events of it. When I arrived in 1974 as young assistant at the University of Namur, I was requested by my dean to participate in a seminar you organised at the Computer Science Institute entitled "L'Homme et l'Informatique". The only reason for having being designated was - I am afraid - the fact that as the youngest at the Faculty I was unable to refuse so modern a discussion. Through this fruitful participation I discovered the "ICT world" but, more importantly, found your open-minded personality really fascinating. You wanted to confront two kinds of norms: the legal norms and the technological ones. We have spent hours and hours analysing the first Belgian Bill on Data Protection, trying to achieve between us a common understanding and analysing the mutual impacts of our distinct scientific approaches. It was the origin of the Research Centre on Computers and the Law (CRID, in 1979). Ten years later, we enlarged this interdisciplinary approach of the technological development by creating together the Interfaculty Research Group on Technology Assessment (CITA). With Claire, who has succeeded you as CITA director, I would like to repeat, dear Jacques, my profound gratitude for these CITA and CRID adventures, both still ongoing and - as I am deeply convinced - more and more needed in our Information Society. Technological development must be assessed from a societal point of view and modelled according to values chosen after a democratic debate. Internet governance precisely has both to organise this debate and to create the regulatory solutions needed in order to achieve the goals determined by this debate. Internet governance is a key issue for the future of the Information Society. The debates of the second WSIS during its preparation and the Tunis Conference ${ }^{2}$ clearly focusing mainly on this concept and its role have demonstrated quite clearly the truth of this assertion.

2. The Geneva WSIS Declaration of Principles might be considered as a first attempt to define a "Global Information Society Constitution". This Constitution asserts new rights for each individual within a global Information Society, particularly the right to participate in the Information Society (which includes not only the right to be

2 In that context one underlines the important and crucial role played by the Working Group on Internet Governance (WGIG). The final report of the WGIG was presented on 18 July 2005. All the information about the work carried out by the WGIG during its mandate is available at: www.wgig.org., particularly the Report from the WGIG (Working Group on Internet Governance) [WSIS-II/PC-3/D]. On the settling-up of this WGIG, see infra footnote 8 3 See particularly, the analogy between the wordings used by the Geneva Declaration of Principles and the US Constitution: "We, the representatives of the peoples ..." 
connected to the infrastructure, not only the right to gain access to the informational richness available on the Net, ${ }^{4}$ but also the possibility for everybody to take part in the large discussion forum which the Internet constitutes. This right to participate has the prerequisite that each citizen must be appropriately educated to use ICTs and the right to express him or herself on the Net in his or her own language ${ }^{5}$.

This Constitution reasserts - with less conviction perhaps ${ }^{6}$ - the importance of human rights (mainly those relating to freedom of expression and privacy) in a global Information Society. Finally, the Geneva Declaration of Principles deals with the problem of Internet governance, submitting rough principles ${ }^{7}$ and requesting the UN Secretary General to create a special Working Group on Internet Governance (WGIG) $^{8}$. The conclusions of this Working Group, which developed certain scenarios, were barely discussed till the day before the opening of the Tunis Conference9. A last-minute compromise was adopted in the end by all contracting parties despite significant disappointment expressed by certain countries, particularly those in the developing world ${ }^{10}$.

$4 \mathrm{~A}$ prerequisite is the positive obligation of the States to put at the disposal of their population certain information of public utility apart from all the information they are collecting from their citizens through modern medias (the concept of public Information services).

5 The defence of the "Multilingualism " on the Internet is definitively linked with this concern (on that point, see the recent UNESCO Convention on the protection and promotion of the diversity of cultural expressions 2005, Paris, 20 October 2005 but also, the UNESCO Universal Declaration on Cultural Diversity, adopted by the $31 \mathrm{sr}$ session of the General Conference of Unesco, Paris, 2 November, 2001 and its Recommendation concerning the Promotion and Use of Multilingualism and Universal Access to Cyberspace, adopted by the UNESCO General Conference at its 32nd session( October 2003). .

6 See, on these liberties, the weak provisions on Freedom of expression, Privacy and fight against Racism and xenophobia enacted by the Geneva Principles: " We should... " ( Points 55,58 and 59 )

7 See, infra, $n^{\circ} 4$

8 According with the decision taken at Geneva, a specific working group was settled up by the UN Secretary General to address this issue and to prepare recommendations for the Tunis Summit: the WGIG (See, Geneva Declaration of Principle, point 50 : "International Internet governance issues should be addressed in a coordinated manner. We ask the Secretary-General of the United Nations to set up a working group on Internet governance, in an open and inclusive process that ensures a mechanism for the full and active participation of governments, the private sector and civil society from both developing and developed countries, involving relevant intergovernmental and international organizations and forums, to investigate and make proposals for action, as appropriate, on the governance of Internet by 2005."

9 Four scenarios have been proposed by the WGIG in its final report (quoted footnote 2) to the WSIS for discussion. These scenarios were based on the following principles:

" 35 .The WGIG addressed the adequacy of current Internet governance arrangements in relation to the principles outlined in the final WSIS documents and came to the conclusion that some adjustments needed to be made to bring these arrangements more in line with the WSIS criteria of transparency, accountability, multilateralism and the need to address all public policy issues related to Internet governance in a coordinated manner. It grouped these issues in four clusters: a forum, global public policy and oversight, institutional coordination, and regional, sub regional and national coordination.

10 It must be recalled that amongst the different scenario proposed by the WGIG, a model including a better control and oversight by the Governments on the international private organisations was supported by a large majority of countries not only developing countries but 
3. Three main points might be developed apart from the two WSIS conclusions on that issue. The first focuses on the basis of this concept and its meaning. The second intends to answer to the question, What new approach is proposed by the WSIS on this topic and do we need this new approach? The third is an attempt to sketch a comparison between the WSIS approach and the European Union approach developed recently by the Inter-institutional Agreement concluded between the European Parliament, European Commission and Council of Ministers, entitled: "Better Lawmaking"11.

\section{Internet Governance: Why and What?}

4. Point 48 of the Geneva Declaration of Principles might be considered as a good summary of the Internet governance concept and basis: "The Internet has evolved from a global facility to the public and its governance should constitute a core issue of the Information Society agenda. The international management of the Internet should be multilateral, transparent and democratic, with the full involvement of governments, the private sector, and civil society and international organisations. It should ensure an equitable distribution of resources, facilitate access for all and ensure a stable and secure functioning of the Internet, taking into account multilingualism." This assertion addresses many issues to which we will come back later, like the so-called "multistakeholder" approach. At this point, we would like just to pinpoint, first, the basis of Internet governance which explains the relevance of this debate as a "core issue" of the Information Society agenda and, second, the regulatory concept to which Internet governance refers.

5. The Internet, asserts the Geneva declaration, has to be considered as a global public good. "Global"12 means that the Internet network has become a worldwide infrastructure without any borders and must be kept as such. At first glance, this assertion might be viewed as obvious. However, one knows that the universal character of the Internet currently faces two major risks of fragmentation. The first

also the European Union, which had joined the developing countries position at the last minute. Japan and US have notwithstanding this large majority maintained their position in favour of a quasi status quo.

11 This Inter-institutional Agreement concluded in October 2003 and signed the 16th of December 2003 ( Doc. 2003/C321/01, C 321/2 , Official Journal of the European Union 31.12.2003) is founded on a large number of previous documents and debates. See firstly the White Paper "European Governance" ( Com(2001) 428 final) submitted by the Commission and approved by the European Parliament Decision of October, the 9th 2003 (O.J. C 81 E/84, 31.3.2004). On this debate, see Y.POULLET, "ICT and Co-regulation : Towards a new regulatory Approach?, in Starting Points for ICT regulation", B.J. Koops and alii (ed.), T.M.C. Asser Press, ICT\& Law 9, 2005, p. 247 and ff.

12 Another sense could be given to the concept. "Global" might also mean that the indefinite number of ICT services and products have invaded the entirety of our lives, following us everywhere, controlling all of our actions and more and more indispensable to our lives. 
comes from states like $\mathrm{China}^{13}$ (but in due course perhaps certain Islamic countries as well), deciding to have their own infrastructures separated from the rest of the Internet, but connected to it through gateways which permit the control of all incoming and outgoing communications, for political reasons. The second trend to the fragmentation is less well known. It relates to the development of large intranets by major companies in order to offer customers their own services. This risks creating a two-tier society, one with the full benefit of these intranets with added value, and the rest of the world using the common infrastructure, which will become poorer and poorer. In that perspective, the slogan "Only one Internet for one world" must be repeated even if this assertion does not exclude possibilities of divergences about the regulatory approach of this common network and about the content of this regulation.

6. "Public" undoubtedly means "accessible to everyone". This conception of the public character of the Internet pleads, as we said previously ${ }^{14}$, for universal accessibility at a reasonable price to services of the infrastructure defined as a minimum requisite. It also implies the right to take benefit of the Internet's informational richness. ${ }^{15}$ And finally it requires providing the capacity to participate actively within Information Society. The importance placed by the Geneva Declaration on educational programmes needed in order to make this dream possible translates this new right. Having recently visited the Niger, I have to confess that this universal access will or many years remain a "myth".

7. In order to maintain the Internet as a global resource and to achieve the dream of it becoming a public good, the Internet must be governed and regulated ${ }^{16}$. The term "regulation" is ambiguous for at least two reasons: the first regards the scope of the term; and the second regards the tools available for ensuring this regulation. The scope of governance might be defined either in a narrow or in a broad sense.

13 On the Chinese Internet policy, see the special report : "China and the Internet : the reality, the people and the power of cybertalk", published April, the 27th, 2006, by the Economist and available on the website: http:/www;economist.com/world/

14 See, supra, $n^{\circ} 3$.

15 This idea of a "Public Domain Content" has been clearly promoted by the UNESCO. See, Point 15 of the "Recommendation concerning the Promotion and Use of Multilingualism and Universal Access to Cyberspace", adopted by the UNESCO General Conference at its 32nd session (Oct. 2003) : "Member States should recognize and enact the right of universal online access to public and government-held records including information relevant for citizens in a modern democratic society, giving due account to confidentiality, privacy and national security concerns, as well as to intellectual property rights to the extent that they apply to the use of such information. International organizations should recognize and promulgate the right for each State to have access to essential data relating to its social or economic situation".

16 ...And its infrastructure financed. The problem of financing the infrastructure in poor countries is addressed partly by the creation of a "Universal Fund "whereof the creation has been requested during the Geneva WSIS preparation. The solution proposed by the Geneva WSIS and repeated by the Tunis WSIS to create a special fund alimented through donations and not structurally by a sort of TOLBIN tax on the electronic flows does not answer to the developing countries. 
Traditionally, the concept of Internet governance covers only the regulation of what we might call the Internet's rare resources which are indispensable for ensuring the functioning of the network. That is, the allocation of domain names and IP addresses. Up to now, these tasks have been ruled by ICANN, a private international organisation ${ }^{17}$. The Tunis WSIS clearly rejected this narrow definition of the scope of Internet governance by referring to the broader definition proposed by the Working Group on Internet Governance created by the UN General Secretary according to his mandate given by the WSIS Conference ${ }^{18}$ : " $A$ working definition of Internet Governance is the development and application by Governments, the private sector, and civil society, in their respective roles of shared principles, norms and rules, decision making procedures, and programmes that shape the evolution and use of the Internet."

8. Thus, according to the Tunis Agenda, Internet governance encompasses all the topics linked with the functioning and the unlimited uses of the Internet products and services, like privacy, intellectual property, consumer protection, electronic communications regulations, multilingualism, freedom of expression, cybercrime, etc. Notwithstanding this broad definition, it must be underlined that during the preparation of the second WSIS, during the debates on Internet governance, the attention focused mainly on the Internet Governance concept in the narrow sense. An explanation for this might be found in the fact that the US Government was particularly concerned to maintain its present domination on ICANN through subtle mechanisms like the Memorandum of Understanding signed between the ICANN and the US Department of Commerce19, which ensures a certain right to oppose to the US Government and certain control prerogatives particularly as regards the allocation of root servers. Any debate about a shift in the structure and management of ICANN was systematically blocked by US government representatives. This attitude effectively prohibited any debate about the significance of the extension of the Internet governance concept. The final outcome of all the discussion was to maintain ICANN outside of the rest of the Internet Governance, by dissociating artificially the so-called "operational management " of the Internet (the day-to-day operations) reserved to ICANN and the other "eldest " Internet Governance issues.

9. The second major point as regards the concept of "regulation" is the list of normative tools to which the concept refers. On that point, one might note the enlargement of the tools by which regulation might be expressed and enacted. The text mentions explicitly: "norms, decision-making procedures, and rules". It is quite noticeable that in the traditional way to regulate (i.e., public legislation),

17 As regards the ICANN organs, rules of procedure, have a look at the ICANN website available at : http://www.icann.org. .

18 On that point, see supra $n^{\circ} 2$ in fine.

19 About this MoU concluded between The US Department of commerce and the ICANN, read the different articles written by $M$. FROOMKIN notably, "Of governments and Governance", Berkeley Technology Law Journal, $n^{\circ} 2,199$, available on the Internet at : http://www.law.berkeley.edu/joumals/btlj/Articles/Voll4/Froomkin/html/reader.html and of the same author, "Wrong turn in Cyberspace: Using ICANN to round Around APA and the Constitution", Duke Law Journal, 2000, p. 17 and ff. 
international treaties are not mentioned. So WSIS clearly encourages a multinormative system and affords a great importance to self-regulatory or co-regulatory norms considered on an equal footing as the public regulations adopted according our Constitutions after a parliamentary debate. We will come back to this point (see, infra, $\mathrm{n}^{\circ} 15$ and $\mathrm{ff}$ ).

\section{New WSIS Principles related to Internet Governance}

\section{A. An ambiguous techno-legal global approach}

10. The first principle asserted by the WSIS should be stressed. Through different provisions enacted in their final declaration, the States' representatives present at WSIS recognize the importance of the technical issues in the shaping of the regulatory issues ${ }^{20}$. "Governance encompasses both technical development and public policy." This attitude is well-founded insofar as the technical choices might affect the legal issues. So, for example, the IETF norms, which have made possible the use of cookies, have a direct impact on Privacy issues and it is clear that the IPv6 norms launched by ICANN together with IETF create new threats as regards data protection $^{21}$. In the other sense, it has to be recognized that through certain technical tools the effectiveness of certain rights directly derived from legal provisions is better guaranteed. For example, Digital Rights Management (DRM) systems are protecting the copyright of the author ${ }^{22}$ better than our jurisdictions and legislative documents. So the recognition by WSIS of the potential impact of the technology on the regulatory framework justifies a reinforced dialog between computer scientists and the standardization bodies and the other regulatory partners and compels a clear request for a more transparent and debated discussion on the technologies and their impacts. Apart from these assertions, it would be nice to go a step further and to proclaim the necessity of a techno-legal approach which ensures that the technologies fit into the legal requirements and above that, bring an added value ${ }^{23}$ in the effectiveness of these requirements.

20 On the relationships between Technology and Law, see amongs others, D.L.BURK," Comments on 'Should ICT Regulation be undertaken at an International level", in Starting Point for ICT regulation, already quoted footnote 11, J. REIDENBERG, "Lex Informatica: The formulation of Information Policy through Technology", Texas Law Review, 1993, p. 553 and ff. , Y. POULLET, "Technology and Law: from alliance to challenges", in Information Quality Regulation: Foundations, ,Perspectives and Applications, U. Gasser (ed.), Baden-Baden, 2004.

21 L. LADID, "IPv6 Roadmap", in Foresight of the Internet, M.A. Delahaut (ed.), Institut Jules Destrée, Namur, 2005, 395 and ff.

22 About DRM, S. DUSOLLIER, Droits d'auteur et protection des oeuvres dans l'univers numériques, Thèse, Larcier, 2005.

23 On the "added value principle ", see notably the conclusions of the EU e-confidence Forum ( http://www.econfidence.jrc.it/default ). Authors speak willingly about the "Rights Enhancing Technologies". It is quite obvious that the Technology might help as regards the enforcement of the legal rights granted by the legislative texts. On that point with certain criticisms about the fact that Technology deserves necessarily the legislative objectives, read 
11. Certain declarations in the Tunis Agenda indicate that this conclusion in favour of such a techno-legal approach has not yet been accepted insofar as the agenda maintains a partition of roles between the Government, on one hand, and the worldwide technical and private organisations (particularly ICANN), on the other. Point 69 of the Tunis Agenda asserts that governments have "to carry their roles and responsibilities in international policy issues pertaining to the Internet", and adds immediately "but not in the day to day technical and operational matters that do not impact on international policy issues".

In other words, the WSIS blows hot and cold. On one hand, WSIS asserts the need for Internet Governance that takes into account all aspects of technical development but at the same time, on the other hand, WSIS is unable to assert definitively that all technical developments have to be controlled in a way that ensure their compliance with regulations. An ambiguous separation is maintained between operational management outside of the control of the public governance and fixation of essential public objectives. Internet Governance remains divided into two regulatory spheres separated ${ }^{24}$ and from points 55 and 57 of the Tunis Agenda, WSIS makes clear according to the US pressures ${ }^{25}$ that there is no demand to modify the present situation: "We recognise that the existing arrangements for Internet governance have worked effectively to make the Internet the highly robust, dynamic and geographically diverse medium that is today, with the private sector taking the lead in day to day operations, and with innovation and value creation at the edges...The security and stability of the Internet must be maintained.". These provisions refer to ICANN's present competencies, which must be kept outside of the sphere of action of governments ${ }^{26}$, except for the role already played by the Governmental Advisory Committee (the so-called GAC) imposed by the European Union on ICANN a few years ago ${ }^{27}$.

P. SCHWARTZ, "Beyond Lessig's Code for Internet Privacy", Wisconsin Law Review, 2000, p. 743 and ff (especially, p. 787).

24 About this partition into two regulatory worlds, the reflections still valuable proposed by REIDENBERG in "Rules of the Road for Global Electronic Highways: Merging the Trade and Technological Paradigms", 6 Harvard Journal of Law and Technology, 1993, p. 287. More recently, G. SARTOR, „Virtual Rules and Internet Law“, in Informatik- WirtschaftRecht : Regulienung in der Wissensgeselleschaft, Festschrift fûr W. Kilian, J. Taeger and A. Wiebe (eds), Nomos Verlagsgesellschaft, Baden-Baden, 2004, p; 571.

25 "The US government will continue to maintain 'oversight' of ICANN and prevent its focus' from straying from technical coordination."( McCullagh," US to retain control of Internet domain names", New York times, July 1, 2005.

26 See however the Point 68 of the Tunis Agenda: "We recognise that all governments should have an aqual role and responsibility for International Internet Governance and for ensuring the Stability, security and continuity of the Internet." This point taking again the same wording than the Point 57 seems quite contradictory with this one.

27 See the gac.icann.org: The web site of ICANN's Governmental Advisory Committee (GAC), which considers and advises ICANN on its activities as they relate to concerns of governments, particularly matters where there may be an interaction between ICANN's policies and various laws and international agreements or where they may affect public policy issues. On its role, see notably, C. WILKINSON," Transversal Issues of the Internet Governance", in Foresight of the Internet, already quoted supra footnote 21. 
Perhaps the termination next year of the Memorandum of Understanding signed between the US Department of Commerce and ICANN, whereby the US Government exercises secret but effective control on ICANN Board decisions, will lead to a more international form of control operated by international public organisations. That was the scenario supported by a large majority of countries during the debates preceding the WSIS. At this moment, the artificial distinction between two regulatory worlds - the day-to-day technical and operational management, and the public policy objectives - prevents a real assessment of the compliance of the technical developments with the public policy goals asserted by the Governments or public international organisations.

\section{B. A pro-active participatory democracy opened to all stakeholders}

12. The second principle also merits our attention. WSIS strongly and proactively supports "participatory" democracy or "multistakeholder governance". " There is a need to initiate, reinforce, as appropriate, a transparent, democratic, and multilateral process, with the participation of governments, private sector, civil society and international organisations, in their respective roles." The idea of promoting this multistakeholder approach of governance- a "leitmotiv" throughout the Tunis documents (it was already present in the Geneva documents)- is central in the Tunis document. It means two different things: the first refers to the need for ensuring in Internet governance the involvement of all categories of interested parties; the second confers to each of these stakeholders a particular role in governance.

\section{a. The stakeholders}

13. On this second point, the Tunis Agenda again takes the principle already enacted by the Geneva Principles: "The management of the Internet encompasses both technical and public policy issues and should involve all stakeholders and relevant intergovernmental and international organizations. In this respect it is recognized that:

a) Policy authority for Internet-related public policy issues is the sovereign right of States. They have rights and responsibilities for international Internet-related public policy issues;

b) The private sector has had and should continue to have an important role in the development of the Internet, both in the technical and economic fields;

c) Civil society has also played an important role on Internet matters, especially at community level, and should continue to play such a role;

d) Intergovernmental organizations have had and should continue to have a facilitating role in the coordination of Internet-related public policy issues;

e) International organizations have also had and should continue to have an important role in the development of Internet-related technical standards and relevant policies. ". 
Two additional actors are indicated by the Tunis Agenda, although the role they play must be seen within the context of the already mentioned stakeholders: "We recognize the valuable contribution by the academic and technical communities within those stakeholder groups mentioned in paragraph 35 (the above mentioned stakeholders) to the evolution, functioning and development of the Internet."

14. Nevertheless, the separation of roles proposed by the WSIS among the different parties must be stressed. The major and prominent role is assigned to the national governments as regards major decisions on "Internet related public policy". The assertion is meaningful insofar as despite the ever greater interdependency created among the nations by the global network of the Internet; WSIS reasserts the principle of sovereignty of each nation in its choice of the essential public policy objectives. Perhaps this assertion might be viewed as purely wishful at a moment where the global surveillance mechanisms made possible by the Internet ${ }^{28}$ and the global Information Society economy renders this sovereignty principle in part as outdated. Apart from now, sovereignty will be considered more and more both as the right to regulate independently the domestic aspects of the public policy regulation of the Internet and as regards the increasing international aspects of this public policy as the right for each nation to be heard and to participate in the international governance on an equal footing. The distinction between both aspects remains unclear. Is it still possible to assert the principle of "subsidiarity" when the Internet is abolishing frontiers and makes difficult any national policies ${ }^{29}$ except for powerful countries or countries working together in regional organisations like European Union ${ }^{30}$ ?

15. The second role is to be played by the private sector. The principle quoted above underlines the "important role" the private sector has as regards the economic and technical aspects. This assertion is at least ambiguous. Does it mean that the regulation on economic aspects like the development of e-commerce or on technical aspects must be initiated by the private sector and that technical development is in the hands primarily of private companies or does it mean simply that the private sector is the leader of the development of both the e-economy and the technology? It is quite clear that the second significance is so obvious in a liberalised market that only the first meaning might be retained. In that perspective it means that

28 So, ECHELON, the US and UK system of surveillance of electronic communications conveyed by satellite illustrates that our democracy might be more and more controlled by foreign governments through the technology means. The E.U Parliament has severely criticised precisely for this reason the ECHELON system and adopted a strong resolution claiming for a reassertion of the EU sovereignty against this global surveillance of EU citizens including business and administrations. On the ECHELON case, see D. YERNAULT, " De la fiction à la réalité: le programme d'espionnage électronique global "Echelon" et la responsabilité internationale des Etats au regard de la convention européenne des droits de l'homme ", in Rev. Belge de droit international, 2000/1, p. 135 and ff.

29 On that issue, the Discussion Paper published by the Law Commission of Canada, " Crossing borders : Law in a globalized World", March 2006.

30 About the EU policy on the Internet, our reflections in Y. POULLET," A European Internet Law ?", in Informatik-Wirtschaft-Recht, already quoted supra footnote 24, p. 533 and ff. 
international business associations like the Global Business Dialog (GBDe) ${ }^{31}$, the International Chamber of commerce (ICC) or the Business and Advisory Committee (BIAC) have a leading role as regards regulatory initiatives concerning public policy issues which might favour the economic development of the Internet ${ }^{32}$. If we accept this second meaning we might consider that WSIS pleads in favour of self-regulatory norms avoiding as far as it is possible the intervention of the State.

16. The role of the Civil Society that means the intervention of Civil liberties Association ${ }^{33}$, Trade Unions and Consumer Protection associations, remains, according to the wording used by the WSIS, unclear. What does mean playing a role "on Internet matters, especially at the Community level"? Their role seems limited to disseminate the different ICT products and services by creating a certain awareness of their benefits among people envisaged at a local or professional level. That interpretation seems however in contradiction with the principle of the multistakeholder approach that implies a real participation of all interested parties including the Civil Society representatives in the definition of the regulatory solutions to the Internet issues and challenges at all the levels: participation in the drafting, control and evaluation of the self-regulatory norms ${ }^{34}$, active involvement in the debates around the public policy issues and initiatives for ensuring the universal access to the Information Society. Perhaps a more positive wording of the role of the Civil Society would have been welcomed. So, a positive obligation towards the private sector to ensure this participation and the duty of the Governments to support the NGOs in order to give them the opportunity to play effectively their role in the Internet governance would have been needed. One knows the financial and human weaknesses of the Civil Society unable till now to play the role of a real counter power vis-à-vis the Business Associations in the discussions about the development of the Internet Society. On that point, we might make reference to the EU policy that

$31 \mathrm{GBDe}$ ( http://www.gbde.org ) is an initiative of some big company chiefs of the calibre of America Online, Time Warner, Fujitsu, MCI, KODAK, ABN AMRO, Vivendi Universal, Alcatel, etc. which examines issues related to security, consumer confidence, IPR, Taxation questions and personal data questions. Different Summits have been organised by this worldwide private organisation (Tokyo, 2001, New York, 2003, Kuala Lumpur, 2004). These annual summits are called the "Davos of e-commerce". The EU Commission report, the famous Bangemann report issued in 1999, was definitively at the origin of this association by pleading strongly in favour of the leadership of the market for regulating the development of the Information Society. On this organisation, C. PRINS," Should ICT regulation be undertaken at an international level?", in Starting points for ICT regulation, already quoted, footnote 11, p. 162 and ff.

32 The three quoted organisations ( ICC, GBDe and BIAC) have signed in that sense an agreement with $\mathrm{OECD}$ on the problems of electronic commerce; agreement signed on December the 13th, 2000: "The GBDe, the ICC and the BIAC are working together to further their international cooperation in all areas of general politics linked to the Internet (on the fullrange of public policy issues arising from the Internet)."

33 Most of these Civil Liberties Associations active in the field like EPIC, ACLU, etc. are mainly located in US (except the EU based EDRI).

34 As regards the consumer protection we underline the Transatlantic dialog between Consumer and Business Associations ( T.A.C.D.) 
foresees the obligation to a dialog between the private sector and the Civil Society representatives ${ }^{35}$.

17. Finally two kinds of international organisations are mentioned: the intergovernmental ones (all international public bodies at the global level but also at the regional level), and international organisations (mainly private organisations acting at a global level, such as IETF, ICANN, W3C, ...). Point 35 of the Tunis Agenda describes the role of the first ones as pure facilitators and coordinators of Internet public policy issues. It is quite clear that their role, as a result of the global nature of the Internet, will increase. However, no direct competence is granted to them by the Geneva or Tunis documents, even though numerous regulatory initiatives (unfortunately not sufficiently coordinated) have been taken by most of them. We will come back to the problem caused by the multiplicity of international public organisations and the timid progress proposed by the WSIS on that field. As regards the second kind of actors, the text speaks about their "important role" in relation to technical standards and relevant policies. This assertion might be considered as an international consecration of the competence of these private international non-profit organisations born with the Internet ${ }^{36}$ and having developed progressively their regulatory competences on the net ${ }^{37}$ Let us recall that the Tunis Agenda maintains a certain autonomy (supra, $n^{\circ} 11$ ) to these organisations for regulating the technical questions and, as asserted by Point 35," the relevant policies" linked to these technical standards. What does the extension of the prerogatives of these bodies in the "definition of the policies linked with technical standards" mean? Everyone agrees that with the philosophy of the $\mathrm{W} 3 \mathrm{C}$, openness and decentralisation have been incorporated into the technical norms of the WWW to the point that today they are defined as its characteristics, but to what extent this philosophy of the Internet might or might not be endorsed by certain Governments which the WSIS proclaims as independent? Another example: if the W3C imposes the $\mathrm{P} 3 \mathrm{P}$ as the adequate means for protecting privacy through an agreement between all terminal equipment producers, to what extent might a so-called sovereign State refuse this standard as providing an insufficient data protection ${ }^{38}$ ?

\section{b. "Participative democracy": Who are the winners and the losers?}

18. This multi-stakeholders approach might be held as a substitute for the traditional "representative and national democracy", which might be considered as being unable

35 See infra, $\mathrm{n}^{\circ} 24$

36 So IETF is born in 1986 at a moment where the Internet was just a scientific network joining a few American universities and certain rare private research laboratories. The W3C was founded in 1994, the same year as the WWW protocol.

37 So IETF is born in 1986 at a moment where the Internet was just a scientific network joining a few American universities and certain rare private research laboratories. The W3C was founded in 1994, the same year as the WWW protocol.

38 See, on this point the debate between LESSIG, ROTHENBERG and SCHWARTZ described in the author's article, "Technology and the Law: from Alliance to Challenges", quoted supra footnote $n^{\circ} 20$. 
to respond to the challenging questions of a global Information Society. However, it raises a number of questions. For example, it seems that the distinction between the prominent roles played by the national States in the definition of public policy, on one hand, and by private actors as regards the technical and economic aspects, on the other might be questioned insofar as all the societal aspects, including technological and economic developments, are interrelated and might not be dissociated as before. The procedures by which this new governance model might function are not defined and one might fear that the partners playing in this multi-stakeholders' democracy are not on an equal footing. Among the States, it is quite obvious that certain powerful countries might impose to others their points of view. Certain commentators are denouncing the lack of international organisations uniting the civil society associations at a global level and thus their intrinsic weakness in the global dialogue.

19. The Internet Governance Forum (IGF) set up by the Tunis WSIS might be seen as a first implementation of this new democracy but its creation and the limits of its competence illustrate quite clearly the difficulty to translate concretely the new approach. If the mandate given to the IGF through the Tunis Agenda is to discuss "public policy objectives", its statute must be elaborated in order to join together all stakeholders, the same Agenda demands that this IGF should not be allowed to exercise competences that are already assigned to already existing international organisations. Much care will need to be taken to ensure thqt the topics submitted to this Forum are limited to secondary regulatory questions like spam and cybercrime. The problems of how to organise the representation of all stakeholders both on a geographical and on a sectoral basis and how the resolution might be elaborated and approved. This has not yet been solved.

20. The two WSIS summits intend to formalise a new equilibrium between the policy makers of the Information Society. In that context we might consider that certain international organisations, namely those in charge of the WSIS follow-up ${ }^{39}$ : $\mathrm{UNESCO}^{40}$ and to a lesser extent ITU, have gained increasing power over the other international public organisations. It is quite instructive to underline that UNESCO

39 See, the Point 103 of the Tunis Agenda: "We invite UN agencies and other intergovernmental organizations, in line with UNGA Resolution $57 / 270 \mathrm{~B}$, to facilitate activities among different stakeholders, including civil society and the business sector, to help national governments in their implementation efforts. We request the UN Secretary-General, in consultation with members of the UN system Chief Executives Board for coordination (CEB), to establish, within the CEB, a UN Group on the Information Society consisting of the relevant $\mathrm{UN}$ bodies and organizations, with the mandate to facilitate the implementation of WSIS outcomes, and to suggest to CEB that, in considering lead agency(ies) of this Group, it takes into consideration the experience of, and activities in the WSIS process undertaken by, ITU, UNESCO and UNDP".

40 So it is quite clear that the recommendation issued and adopted by UNESCO in 2003 about "Recommendation concerning the Promotion and Use of Multilingualism and Universal Access to Cyberspace", adopted by the Unesco General Conference at its 32 nd session (Oct. 2003) was definitively a sign of the UNESCO will to play an important role in the WSIS discussion and to influence the discussion of the WSIS summit. 
and $\mathrm{ITU}^{41}$ are explicitly designated for "moderating and facilitating", each in its sphere of competence, the dialogue between the stakeholders in order to achieve the Geneva Plan of Action ${ }^{42}$.

That reinforcement of these institutions corresponds to the express wish of the UN Secretary General, who gave them the mandate to organise the two WSIS conferences just at the time when UNESCO and the ITU were considered "poor and weak" in comparison with other international public bodies like WIPO or WTO, and as a result of the increasing power of the international private organisations. On that point, one might recall that at the moment in 1992 where discussions took place as regards the adoption of the TCP/IP norms in order to ensure a full interoperability of the Internet network, ISO and ITU were unable to face the challenge and the supple IETF organisation founded on the "rough consensus principle" appeared more appropriate to fix the norms even without official delegation from these public international organisations ${ }^{43}$. UNESCO's competence in issues related to Internet governance was challenged to the benefit of WTO and OECD (on issues related to international commerce) and WIPO (on IPR and Internet issues).

21. WSIS was also an opportunity for asserting the absolute need for a better coordination between the different international public bodies, beyond their traditional partition of competences. $U p$ to the present, each international organisation was in charge of a specific topic without taking into account the need for a global or at least horizontal approach for regulating the Internet. IPR issues cannot not be discussed without taking into account the impact of the regulatory solutions on the problems of access to information, computer crime and privacy issues. The legitimate interests and rights of copyright holders favoured by the WIPO must be evaluated vis-à-vis the cultural and scientific developments requirements, which are among UNESCO's concerns and, as a possible trade barrier, within the scope of WTO. Finally, it was granted to ECOSOC, a UN General Assembly division and, more particularly inside ECOSOC, the UN Commission on Science and Technology for Development44, the mission to "oversee the system wide follow-up of the Geneva and Tunis outcomes of WSIS".. By this overseeing activity, a certain control of the dialog of the stakeholders and a competence of initiative was granted to the public international organisations by virtue of the better coordination between them and by strengthening of their mandates, the WSIS gives to the public authority an unique chance to regain the leadership of Internet governance even if at the same

41 UNDP is also in charge of certain missions (see Point 103 of the Tunis Agenda, quoted supra footnote 39 .

42 Annex A of the Tunis Agenda offers the list of areas which are under the responsibilities of the UN Agencies and particularly of these three leading UN Agencies. The UNESCO has definitively the prominent role.

43 On that debate, read J. BERLEUR- Y. POULLET, "What Governance and regulations for the Internet ? Ethical issues", in The Information Society: Emerging Landscapes, Proceedings of the IFIP Intern. Conference, Turku, June 27-29, (ed. C. Zielinsky, P. Duquesnoy and K.Kimppa), Springer, IFIP, 2005, p. 171.

44 ...whose composition, mandate and agenda must be renewed, "including the strengthening of the Commission, taking into account the multi-stakeholders approach"( Point 105 of the Tunis Agenda). See also, 
time, the WSIS documents for the first time grant an important role to private organisations without claiming any modification of their statutes ${ }^{45}$ or putting them under the tutelage of the public authorities.

22. All in all, the movement initiated by WSIS in favour of a new Internet governance framework is thus slight insofar as it does not imply any revolution in the present situation. It is also full of ambiguity insofar as the WSIS documents might be considered either as a victory of the new private regulatory forces, or as being behind the recognisance of these new regulators as a way of reintroducing public authorities as leaders. Furthermore, the regulatory framework sketched out by WSIS, if it envisages different regulating actors and roles, insufficiently elucidates the links between the norms elaborated by them. So many questions still remain. To what extent should the private sector ensure civil society participation in the drafting procedure envisaged for the self-regulatory norms? Does this selfregulation have to comply with the various norms enacted by national or international public bodies? How can the control of this compliance be ensured? Do we still need public regulatory norms? To answer these questions, a short analysis of the recent European inter-institutional agreement concluded between the European Parliament, the European Council of Ministers and the European Commission of the European Union entitled "Better Law-making” might be useful.

\section{Towards a new regulatory framework? Beyond self- regulation and co-regulation: the "Better Law-making" European model as a solution?}

23. I would like to comment very briefly on the recent Inter-institutional agreement entitled "Better Law-making" concluded between the three legislative authorities of the European Union - the European Parliament, the European Commission and the Council of Ministers - in order to ameliorate the legislative production and quality of European legislation ${ }^{46}$. On the role of the legislative action, Point 16 states: "The three Institutions recall the Community's obligation to legislate only where it is necessary, in accordance with the Protocol on the application of the principles of subsidiarity and proportionality. They recognise the need to use, in suitable cases or where the Treaty does not specifically require the use of a legal instrument, alternative regulation mechanisms."

The text clearly asserts the double "subsidiarity" of the legislative approach" the first of these was already asserted as a fundamental principle of the European Union according to article 5 of the European Treaty, which states that European

45 Except the general call for a more effective multi-stakeholder approach: "A multistakeholder approach should be adopted, as far as possible, at all levels". This purely votive assertion is however insufficiently precise to assert that modification are really requested.

46 See, the references given supra, footnote 11 . The agreement does envisage all the societal issues and not only those raised by the Information Society development even if these specific issues are mentioned as a test case by the White paper.

47 On this principe, F. DELPEREE (éd.), " Le principe de subsidiarité ", Bib. Faculté de Droit de l'UCL, LGDJ-Bruylant, 2002. 
Union institutions may only act on matters that cannot be more adequately ruled at an inferior level ${ }^{48}$. According to that statement, the "subsidiarity" principle asserts clearly that local solutions are still needed and must be preferred to international or global solutions even if this international or European level might procure the general framework wherein these local solutions will take place and interoperate: "Think Global, Act locally". In other words, local or sectoral solutions are the best way to take into account the cultural and business peculiarities of each situation and to develop adequate solutions. Otherwise the regulation will be reduced to an enumeration of vague and broad common principles.

In addition, the combination of the subsidiarity and proportionality principles leads the European Agreement to additional reflections ${ }^{49}$. It imposes the rule that one should not legislate when there are other means to achieve public objectives, particularly self-regulation ${ }^{50}$ or to legislate only to the extent necessary to set these public objectives leaving it to the private sector to decide on the right way to reach them; co-regulation. Thus, the Agreement envisages these two principles as a way to validate and to fix the limits of the coexistence between the traditional regulatory model: the public one and the so-called "modern" ones: self-regulation and coregulation. Everything that can be better solved by co-regulation or self-regulation must be fixed in such ways. Many prestigious authors have broadly asserted the complementarities of the two regulatory models ${ }^{51}$.

48 About this first traditional meaning, see J. VERHOEVEN, " Analyse du contenu et de la portée du principe de subsidiarité ", in F. DELPEREE, quoted footnote 47, p. 376 et s.

49 See on that point, the TIMSIT's reflections (" Les deux corps du droit- essai sur la notion de régulation ", Rev. Française d'Admin. Publique, 1996, p. 375 and ff.) about this new normative approach : " Lorsque l'Etat moderne est apparu, il a en effet trouvé sa traduction dans une droit qui conservait des origines historiques de son Auteur, l'Etat, le caractère mystique et abstrait dont celui-ci était paré. C'est ce droit qui a été le premier corps du droitun droit abstrait, général et désincarné que $\mathrm{j}$ 'appelle le droit-réglementation....Abstrait et désincarné il ne correspond plus aux exigences de la gestion des sociétés post-modernes. Trop complexes pour être gérées aussi généralement, abstraitement et pour ainsi dire d'aussi loin, elles requièrent un autre droit- actuellement en formation- qui se caractérise, au contraire par son adaptation au concret, son rapprochement des individus, son adéquation au contexte exact des sociétés qu'il prétend régir. Concret, individualisé, contextualisé, c'est un droit que j'appelle de régulation. Le paradoxe est que ces deux corps du droit-de réglementation et de régulation- le second n'a été jusqu'à présent, ni connu, ni reconnu... " ( p.377 ).

50 About the different merits of the self-regulation compared to the State regulation, read the good synthesis and the references proposed by C. LAZARO ( "Synthèse des débats", in Gouvernance de la société de l'information, Berleur et alii (ed.), Cahier du Crid, $n^{\circ} 22$, p. 161 and ff.). See also, B.J. KOOPS, M.LIPS, S.NOUWT, C.PRINS and M. SCHELLEKENS, "Should self-regulation be the starting point?", in Starting Point for ICT regulation, ,quoted footnote 11

51 See recently, P.TRUDEL, " L'influence d'Internet sur la production du droit ", in Le droit international de l'Internet, Bruylant, Bruxelles, 2002,p. 87 and ff.: "Pour y obtenir des énoncés normatifs efficaces, il faut exprimer le droit en ménageant des ouvertures vers les autres normativités. " . Cf. also, A.M. SLAUGHTER, "The real New World Order", (1997) 76 Foreign Affairs, pp.183-184; J. REIDENBERG," Governing Networks and Cyberspace Rule Making", 45 Emory Law Journal, 911 (1996) ; E. KATSCH, " Law in a Digital World, NewYork ", Oxford University Press, 1995, p. 20 and ff. .This principle of complementarities is developed broadly in the Environmental regulation where one assists to a multiplication of self-regulatory and co-regulatory beyond the legislative intervention. On this point, see 
24. These principles enacted, the Agreement imposes certain limits on the alternative modes of regulation, self- and co-regulation. Point 17 precise: "The Commission will ensure that any use of co-regulation or self-regulation is always consistent with Community law and that it meets the criteria of transparency (in particular the publicising of agreements) and representativeness of the parties involved. It must also represent added value for the general interest. These mechanisms will not be applicable where fundamental rights or important political options are at stake or in situations where the rules must be applied in a uniform fashion in all Member States. They must ensure swift and flexible regulation which does not affect the principles of competition or the unity of the internal market". The text stresses three main conditions for the enactment of self-regulatory or co-regulatory norms. As regards the application of the triple criteria of the legal validity of a norm ${ }^{52}$, one underlines:

notably, B. JADOT, " Le pouvoir de gérer les questions d'environnement, faire confiance a priori au " privé " ou au " public ", in F. Delpérée (ed.), Le principe de subsidiarité, op. cit., p. 212 et $\mathrm{s}$.

52 The three criteria of the validity of a self-or co-regulation have been extensively developed by the author in a previous essay taking into account the reflections proposed by $R$. SUMMERS (Y. POULLET, "How to regulate Internet: New Paradigms for Internet Governance", in Variations sur le droit de la société de l'information, J. Berleur et alii (ed.) Cahier du CRID, $\mathrm{n}^{\circ} 20, \mathrm{p} .130$ et $\mathrm{s}$. These three criteria are defined as follows:

"The "legitimacy" is "source oriented and underlines the question of the authors of a norm. To what extent, might the legal system accept a norm elaborated outside of the actors designated by the Constitution or under constitutional rules? This quality of the norm means that the authorities in charge of the norm promulgation must be habilitated for doing that by the community or communities of the persons which will have to respect the rule they have enacted. This legitimacy is obvious as regards the traditional State authorities acting in conformity with the competence devoted to them by the Constitution. It is less obvious when the regulation is the expression of private actors themselves as it is the case with selfregulation, particularly when it is the fact of certain obscure associations or even of private companies able to impose their technical standards.

-The "conformity" is " content oriented " and designates the compliance of normative content vis-à-vis fundamental society values, those embedded undoubtedly in the legal texts but also beyond that those considered as ethical values to be taken into account by the legal system. Again this criterion is quite easy to satisfy and to verify in case of traditional texts issued by governmental authorities insofar these texts must be taken in consideration of already existing rules with superior values. It seems more intricate to satisfy to this criterion when the compliance with existing legislative text is not systematically checked insofar these texts are not existing or not clearly identified. Indeed self-regulation is often a way to avoid the traditional and constitutionally foreseen regulatory methods of rule-making.

- Finally, the "effectiveness" is "respect oriented". To what extent, a norm will be effectively respected by those to whom the norm is addressed? So, the question about the information about the existence of the norms, about the sanctions and the way by which they might be obtained are central for determining the effectiveness of a norm. By this criterion, one means in particular the fact for the addressees of the norm to be aware of the content of the norm but also for norms to foresee a cost for its non respect by addresses who are so stimulated to follow the rule. " 
- As regards the "legitimacy" criterion: the text requires the "representativeness" of the parties involved and the transparency of the procedures followed within the selfor co-regulatory process.

- As regards the "conformity" criterion, the principle of "added value" is repeated. The mechanisms may be used on the basis of criteria defined in the legislative Act. The idea is again to fight against the rigidity of the legislative solutions and the need to have a supple mechanism for ensuring a continuous adaptation to the problems and sectors concerned. The European Commission ensures the conformity also through mechanisms of notification even control ${ }^{53}$.

- Finally, as regards the "effectiveness" criterion the co-regulation mechanism is deemed as being the right way to attain the objectives defined by the legislative authorities. The main "added value" ${ }^{54}$ of the self-regulation or co-regulation relies on this criterion insofar co-regulation might set up enforcement mechanisms more adapted, rapid and efficient (through label, accreditation, standardization and ADR mechanisms) than the traditional judicial remedies.

25. Points 17 and 22 of the Inter-institutional Agreement define both co-regulation and self-regulation: As regards self-regulation, point 22 stipulates: "Self-regulation is defined as the possibility for economic operators, the social partners, nongovernmental organisations

or associations to adopt amongst themselves and for themselves common guidelines at European level (particularly codes of practice or sectoral agreements). As a general rule, this type of voluntary initiative does not imply that the Institutions have adopted any particular stance, in particular where such initiatives are undertaken in areas which are not covered by the Treaties or in which the Union has not hitherto legislated. As one of its responsibilities, the Commission will scrutinise self-regulation practices in order to verify that they comply with the provisions of the EC Treaty."

The European conception of co-regulation envisages this mechanism not as a way to prepare future public regulation ${ }^{55}$ but as a tool for refining the content of the

53 " These measures may provide, for example, for the regular supply of information by the Commission to the legislative authority on follow up to application on for a revision clause under which the Commission will report at the end of a specific period, ..." (Inter institutional Agreement, Point 21 in fine).

54 The "added value" principle has been enacted quite clearly by the "e-confidence forum" settled up by the DG Sanco in order to define key principles as regards the acceptability of the self-regulatory methods (code of conduct, labelling system and ODR.). As regards these principles, see the e-confidence website available at : http://www.econfidence.jrc.it/default/htm. These principles and more broadly the attitude of the E.U authorities $v$. à $v$. the self-regulation have been commented by the author in : "Vues de Bruxelles: Un droit européen de l'Internet ?", Le droit international de l'Internet, quoted footnote 49 ., p.165 and ff.

55 Without denying the interest of a close cooperation between public and private players in the preliminary consultation phase, which will lead to the adoption of a legislative text, the European Agreement distinguishes clearly this preliminary discussion and the co-regulatory mechanisms. The first concern is envisaged through the obligation imposed to the European bodies to ensure the participation of all interest stakeholders at any step of the legislative process. As pointed out by the White Paper (EU Commission White Paper, "European 
regulation enacted by the public bodies and for implementing concretely it. By doing that, the Agreement underlines the essential place of the co-regulation.: "Coregulation means the mechanisms whereby a community legislative act entrusts the attainment of the objectives defined by the legislative authority to parties which are recognized in the field (such as economic operators, the social partners, non governmental organisations, or associations)".

26. This definition induces a clear separation of the responsibilities of the State, on one side, and the private sector and other interested parties, on the other, in the regulatory process: the legislative authorities have to fix the essential public policy objectives, when the means by which they are met, are fixed together by the public and the private sectors. Apart from defining the end result and objectives fixed by the legislative instruments, the private sector is mainly responsible for providing the short answer to the question: "How should they be implemented?" This separation of responsibilities seems precisely that promoted also by the WSIS Declaration of Principles in Point 49: "Policy authorities for Internet related public policy is the sovereign right of States ... the private sector has had and should continue to have an important role in the development of the Internet, both the technical and economic fields". So, it is clear with the European text that public and private orderings are not on the same footing. There is a sort of hierarchy insofar as the coregulation is viewed not as a substitute for public intervention but as a way to achieve (choice of the means) the end objectives imposed by the framework fixed by the State.

27. A last remark might be drawn from the text. The European approach as regards co-regulation is fundamentally a "top-down approach" 56 rather than a "bottom up approach" following the distinction proposed by the Mandelkern Report (German Bundesministerium des Innern (BMI ${ }^{57}$ ). As regards self-regulation, more flexibility is given to the private sector insofar as Point 22 underlines it: "such initiatives are undertaken in areas which are not covered by the Treaties or in which the Union has not hitherto legislated ". But if self-regulation is left to private initiatives, the State has to ensure a certain control on this.

Governance", ( $\operatorname{COM}(2001) 428$, final,p.12) whose content has been used as the basis for the Inter institutional Agreement: "the quality, relevance and effectiveness of EU policies depend as ensuring wide participation throughout the policy chain - from conception to implementation. Improved participation is likely creating more confidence in the end result and in Institutions which deliver policies". So, the White Paper does suggest a "more effective and transparent consultation at the heart of E.U. policy-shaping" through multiple channels: advisory committees, hearings, on-line consultations

56 See on that point, A. MASSIMO, "The "Better Regulation" Action plan and the Framework Action on up-date and simplifying the Community Acquis", Roma, Oct. 2003 availaible at http://www.astrid-online.it/qualitate/regolazion/Riunione-d/Iniziative/ECPresentazione-Roma_def.ppt

57 Mandelkern Report, ,Modern Staat-Modern Verwaltung Der Mandelkern-Bericht: Auf dem Weg zu besseren Gesetzen“ available at: http://www.staatmodern.de/Anlage/original_548848/ 
By the "top-down approach" qualified also as the "new approach"58 one considers that the essential objectives, fundamental mechanisms and mechanisms as regards the implementation and the control of these objectives must be regulated by Governmental regulations and insofar as it is possible by legislation.

On the other extreme, the "bottom up approach" regulatory mechanism at a certain moment transformed or taken into account by Public Authorities in the drafting of a new legislation.

Schultz and Held ${ }^{60}$ distinguish four cases illustrating the two approaches:

- A legislative text provides the co-regulatory mechanisms and encourages actors of the involved private sector to transpose by self-regulation the objectives pursued by the legislation (top-down approach)

- Self-regulatory mechanisms are surveyed or controlled by the State (bottom to top approach)

- Self-regulatory mechanisms developed in a first step outside of all intervention of the State are integrated after within a legislative text (bottom to top approach).

- Public Actors and Private actors are cooperating under diverse arrangements. Through their complementary and additional interventions which are placed on equal footing, a better enforcement is given to certain rules (bottom up approach).

28. This classification is interesting when we come back on the WSIS debate on Internet governance. The WIPO Internet Domain Name jurisdictional procedure might be considered as an example of co-regulation in this last sense or, as Froomkin" called it, as a "semi private process" that means "a cooperative endeavour between a public body and private interests that is designed to create a body of rules enforced by some mechanism other than direct promulgation by the public body" ${ }^{\prime 62}$.In the same vein, the Uniform Dispute Resolutions Procedures rules have been drafted by an international public body not as intergovernmental resolution $^{63}$ or convention but as a simple Experts' Report approved at the end by

58 As asserted by the European Commission White Paper, 'European Governance', COM (2001) 130 final, p. 7.

59 C. PALZER," La co-régulation en Europe : conditions générales de mise en cuvre des cadres co-régulateurs en Europe ", IRIS plus, 2002-6 ; White Paper, quoted footnote 56, p. 9

60 W. SCHULTZ - T. HELD, „Regulierte Selbstregulierung als Form modemen Regierens“, Hans Budow-Institute für Medienforschung, Hamburg, Oct. 2001, available at: http://www.vrz.uni.hamburg.de/hans-bredow-institute/publikationen/apapiere/8selfreg.pdf 61 M. FROOMKIN," Semi-private international rule making", in Regulating the Global Information Society, C.T. Marsden (ed.), Frontledge, London-New York, 2000, p. 211 and s. ; From the same author, "Wrong Turn in Cyberspace: Using ICANN to route around APA and the Constitution", 50 Duke Law Journal, 2000, p. 17 and ff.

62 According to FROOMKIN, semi private rule-making should not be confused with either negotiated rulemaking a Government agency or other public body meets with representatives of the group who will be affected by the regulation, and seeks to find agreement on rules that can be promulgated and enforced by the Government. True self regulation excludes the participation of a public body

63 As a follow-up to the US White Paper:" Statement of Policy on Management of Internet Names and Addresses" (U.S. Department of Commerce, 1998), the World Intellectual Property Organisation (WIPO) convened an international process to develop recommendations on certain intellectual Property issues associated with Internet domain names (First Internet Domain Name Process: Compatibility between trademarks and domain names (started July 8, 
ICANN $^{64}$ a private non-profit US organization. Without taking again all the details of the WIPO drafting Procedure, broadly criticized by number of authors, one might conclude with Froomkin that: "A semi-private process led by a public body llike the WIPO Internet Domain Name Process) risks combining some of the worst features of both traditional regulation and private ordering: opaque decision-making is easy. In some cases, the process may be managed by body acting outside its jurisdiction. The public-private blind may also insulate the process from judicial review since it falls outside the categories that courts would tend to think of a within their purview" ${ }^{\text {"65 }}$.

All these questions assertions might be also addressed as regards the functioning of ICANN itself. The origin of ICANN demonstrates the deep link between the US government and this "independent" private body ${ }^{66}$. US governmental control is still present even if, responding notably to European Union pressure ${ }^{67}$, a more democratic way of rule-making, ensuring a better participation of the different continents and a more transparent way of deliberating, has been progressively installed ${ }^{68}$. It is quite interesting to underline that one of the major modification introduced has been the

98, ended April 30, 1999); Second Internet Domain Name Process: Compatibility between certain names and domain names (ended Sept. 3; 2001). It is quite interesting to underline the adoption by the WIPO during this process of the Request for comment (RFC - 1 and 2) procedure which is typically used by private bodies like ICANN, IETF and private standardization bodies) and the fact that governments (especially the European Commission.. See the E.U. Commission Reply to the WIPO RFC, Oct.29, 1998) have intervened in the context of this procedure.

64 It must be underlined that only the WIPO secretariat was involved in the drafting of the rules. The rules were forwarded to ICANN without first being approved by the WIPO General Assembly. ICANN adopted the UDR Policy aimed at settling disputes arising out of abusive registration and use domain names.

65 The comparison between this WIPO rule making and the US Federal Agencies' rule making is on that point quite interesting. According the Administrative Procedure Act, certain requirements have to be taken into account by the Agencies. So, the obligations: 1 . to issue a notice of the proposed rulemaking and to ensure its large publication; 2 . to give to everyone the opportunity for comments; 3 . to consider there comments and motivate the attitude of the Agency v. a v. these comments. Finally, it must be underlined that each person affected by the Agency's decision might challenge it before the Court and that for different reasons ("arbitrary and capricious rule", "outside of the reasonable"). On all these points, M. FROOMKIN, "Wrong Turn in Cyberspace: Using ICANN to route around APA and the Constitution", 50 Duke Law Journal, 2000, p. 17 and ff.

66 See P.Mounier, les maîtres du monde, Homo Numericus, March 2000, available at: http://www.homo-numericus.bonidoo.net/article.php3?id_article=138 ; O. ITEANU, L'ICANN, un exemple de gouvernance originale ou un cas de law intelligence?, Homo Numericus, May 2002, available on the Homo Numericus website, article 154; M. FROOMKIN, Form and substance in Cyberspace, 6 The Journal of Small and Emerging Business Law (2002), 1, 93 and ff. quoting S. LYNN, ICANN President : " Each of ICANN's accomplishments to date have all depended in one way or another, on government support, particularly from the United States." R. DELMAS, " Internet, une gouvernance imparfaite ", in Le droit international de l'Internet, quoted footnote 50, p. 279 and ff.

67 On these pressures, read C. DELMAS, eod.loco.

68 Read the interesting debate between PALFREY,CHEN, HWANG, EISENKRAFT :"Public Participation in ICANN" and Mc LAUGHLIN, "The virtues of deliberative Policymaking : A response to "Public Participation in ICANN". 
setting up of a Governmental Advisory Committee (the GAC). That creation illustrates that co-regulation might lead to a reversal of the traditional hierarchy insofar governmental authority has a simple consultative voice in the ICANN's process of rule making. Very severely, C. Albert ${ }^{69}$ noted " This ultimately means we are left with a self-regulatory organization managing core resources of the Internet, directly controlled neither by the governments of this world, nor by the users of the virtual world. Instead at the end of the day ICANN is controlled by the industry protecting their profitable monopolies and to make -everybody outside the US even more concerned about the future of self-regulation-by representatives of the unilateralist US Administration."

29. These criticisms show the dangers linked with certain co-regulatory schemes. The main fear is what economists call "regulatory capture"70 - that regulatory powers are afforded to certain bodies in a non-transparent way. This might be the case when decisions are taken in a non-transparent way. Insofar as co-regulation might create confusion between the competences of public authorities and private bodies, this fear might be well founded. The risk of having rule-making deeply influenced by the interests of a specific group leads to a "spill-over effect" 71 regarding the content of the rule. Another concern is the difficulty of being sure that "those who are affected by conduct that is the subject of particular rules must have some voice in determine the content of their rules"72. This "legitimacy" question of certain co-regulatory norms, especially when the co-regulation is not organized by the law itself, is not easy to solve. It requires transparency in the process of rulemaking and taking all the opportunities given by the Internet to reach a maximum of transparency and open debate ${ }^{73}$. It is quite clear that the intervention in certain co-

69 C.ALBERT, Editorial, From Global Elections to Self-regulation without the Public : How ICANN fails to fulfil its basic promise ?, available at the PCMPL Self-Regulation review, Oct.2003 available at: http://www.selfregulation.info

70 On that issue, E. BROUSSEAU, "Régulation de l'Internet ; l'autorégulation nécessite t'elle un cadre institutionnel ?", Revue économique, $\mathrm{n}^{\circ}$ hors série: Economie de l'Internet, $\mathrm{E}$. Brousseau and N. Curien (ed.), Oct.2001; M. MUELLER, The " Governance " Debacle, How the ideal of Internetworking Got Buried by Politics, available at: http://www.openrsc.org/essays/mueller/govdec/ .

71 So number of authors have denunciated the fact the WIPO rules are focusing mainly on the protection of IPR holders and have not sufficiently taken into account other general interests like competition, privacy questions ( see notably, M. MUELLER," ICANN and Internet Governance, sorting through the debris of Self-Regulation", in Info, 1999, p. 497-520

72 D.POST and D JOHNSON, New Civic Virtue of the Net, quoted, p.5. From the same authors," Chaos Prevailing on every Continent: A new theory of decentralized Decisionmaking in complex systems", 73 Chicago-Kent Law Review, (1999), p.1055 and ff. These authors insist about the absolute need to control the spill-over effects of the self-regulation or co-regulation by a systematic assessment of the different rules adopted by the self-regulatory bodies.

73 See the constant reference to the procedural Ethic developed by Habermas as a way to solve the legitimacy problem raised by these new normative approaches, in M. FROOMKIN, "Habermas@discourse .net: Toward a critical theory of cyberspace", 116 Harv. Law Rev., 2003,p. 800 and M. MAESCHAALK and T. DEDEURWAERDERE, "Autorégulation, Ethique procédurale et Gouvernance de la société de l'information ", in Gouvernance de la société de l'information, quoted footnote 50., p. 77 and ff. 
regulatory schemes of public bodies like GAC or WIPO might create a false appearance of legitimacy what is an additional risk. To conclude on this point, my intent is definitively not to reject any form of co-regulation. On the contrary, certain schemes, such as those promoted by WSIS and the European Union might bring about what is needed by the Internet, that is to say a more decentralized and adapted regulatory framework allowing each community to take its own responsibility and providing certain added value to the legal framework enacted by the national, or even international, constitutional authorities. Other forms of cooperation between public and private authorities should not be excluded but in these cases the three fundamental criteria of legitimacy, conformity and effectiveness must be be scrupulously respected.

\section{Conclusions}

30. International governance of the Internet must correspond to the international dimension of the network. This assertion explains and justifies the WSIS efforts to propose a global Constitution of Cyberspace, envisaging all aspects of Internet governance in one place. But if common rules are needed at this stage, international public organisations are not yet ready to assume this responsibility.

They appear divided ${ }^{74}$, their composition differs from one institution to another and their procedures seem too lengthy and inefficient. In comparison, private international organisations have grown rapidly, they have developed standards and technical norms in the shadow and they are operating the infrastructure, bringing to it stability and security. The private sector, in the same time, is pleading for selfregulatory solutions and seeking their official recognition. Civil Society's voice is progressively emerging even if it remains quite weak among the others.

In that context, the Internet governance debate is the core issue insofar as it calls for a new democratic process at the international level. This democratic process is not easy to put in place since the Internet offers certain governments and private players a unique opportunity to impose their own regulations unilaterally. Burkert ${ }^{75}$ in a recent essay has demonstrated how slogans or "myths", like "Code as Code", "self-regulation" and "internationalisation" are used by certain policy makers to avoid any debate about normative values. To install again the possibility of this fundamental debate on normative values, the WSIS calls for a transparent, egalitarian and multi-stakeholders dialogue, recognizing as a central point of departure of this debate: the sovereignty of the States, which in the Internet Age becomes more and more another Myth. At the same time, WSIS is forced to grant real regulatory

74 M.LIPS," Inventory of general ICTregulatory starting Points", in Starting points for ICT regulation, quoted footnote 11, p. 13 and ff.

75 H. BURKERT, "Four Myths about regulating in the Information Society", in Starting points for ICT regulations, quoted footnote 11, p.239 and ff. :" Technological neutrality, internationalization, Architecture and Self-regulation are not, of course, as they may seem by now, the Four Horsemen of the ICT regulation Apocalypse. However these terms do more than just describe characteristics traits of regulation in the Information Society. They contain a normative agenda precisely by avoiding a discussion of normative values, by setting tools in the place of goals...(and) tend to marginalize other tools with which to build more democratic society."(p.246) 
autonomy to market forces and to private international standardisation bodies. These contradictory movements might find a solution if according with the European approach, certain additional principles are clearly enunciated and made effective. Subsidiarity and proportionality principles must be enacted and, at the same time, the three criteria of self-regulatory or co-regulatory norms must be asserted and controlled. Is that possible? It is quite clear that a condition is a better coordination of the actions taken by the different international public organisations ${ }^{76}$ and their will to speak with a unique voice about the global issues of the Internet.

76 To what extent the ECOSOC, a division of the UN General Assembly, in charge of this general coordination will be able to achieve this huge task as foreseen by the Points 104 and 105 of the Tunis Agenda?

"104. We further request the UN Secretary-General to report to the UNGA through ECOSOC by June 2006, on the modalities of the inter-agency coordination of the implementation of WSIS outcomes including recommendations on the follow-up process.

105. We request that ECOSOC oversees the system-wide follow-up of the Geneva and Tunis outcomes of WSIS. To this end, we request that ECOSOC, at its substantive session of 2006, reviews the mandate, agenda and composition of the Commission on Science and Technology for Development (CSTD), including considering the strengthening of the Commission, taking into account the multi-stakeholder approach." 